\title{
Allergan's Mohawk evergreening patent deal draws criticism, but ultimately may flop
}

Allergan in September irked the biopharma community by transferring patents covering its blockbuster dry-eye drug Restasis to the Saint Regis Mohawk tribe. Allergan was betting that the tribe's legal status, much like that of a foreign state, would shield six Restasis (cyclosporine) patents from intellectual property challenges. But now it looks like this maneuver is moot. A Texas court on October 16 decided that four of the patents were invalid on grounds of "obviousness." Although the ruling that had nothing to do with sovereignty, still, the court had harsh words for Allergan. "Sovereign immunity should not be treated as a monetizable commodity that can be purchased by private entities as part of a scheme to evade their legal responsibilities," the court said, according to a Mylan Pharmaceuticals release. Mylan and other generic drug makers had challenged the patents' validity

"The judge cast significant doubt on whether any other pharma company will pursue transactions like that between Allergan and the tribe," according to Zachary Silbersher, a patent lawyer at the Kroub, Silbersher \& Kolmykov firm in New York. Although the judge didn't issue a ruling in the sovereignty issue, his opinion will carry weight in other patent decisions, according to Silbersher.

Dublin-based Allergan had transferred the intellectual property to the upstate New York nation, and in exchange, the Mohawk tribe was to receive $\$ 13.75$ million and royalties of $\$ 15$ million annually. This move, described as 'renting' sovereignty, had been heavily criticized as a sneaky legal maneuver. Allergan's ploy, if successful, could have severely hampered the ability of generic drug makers to challenge branded drugs through the so-called inter partes review (IPR; Nat. Biotechnol. 34, 1242-1244, 2016) process. This form of patent challenge established in 2011 has been unpopular with branded drugmakers, who blame it for the rise in 'patent trolls'. Intellectual property transfers would offer pharma companies a way to escape a recently created tribunal process that Brent Saunders, Allergan's CEO, has called "double jeopardy."

It was a risky strategy, according to Ronny Gal, a pharma analyst for Sanford C. Bernstein in New York City. "There's a chance of a public backlash against Allergan," The ruling also means Allergan may lose the $\$ 1.4$ billion in annual sales it gleans from Restasis, its second-best-selling drug after the wrinkle injection Botox, sooner than expected. Restasis accounts for about $10 \%$ of the company's annual sales and $15 \%$ of its operating profit, according to Gal. Allergan was counting on the eye treatment having patent protection until 2024.

Allergan has said it will appeal the decision, and the Food and Drug Administration has not yet approved a cheaper

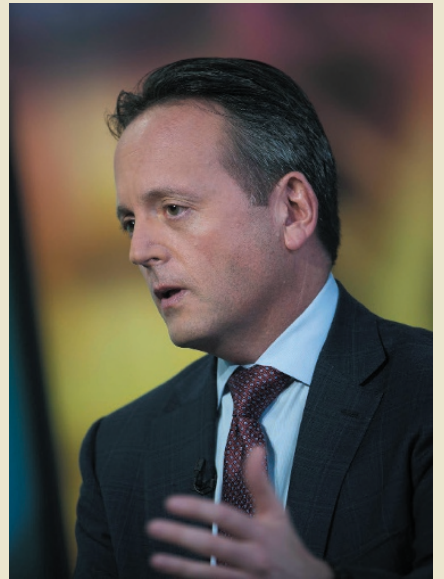

Allergan CEO, Brent Saunders copy of the drug, although Allergan said a generic rival may enter the market in late 2018/ early 2019, but an earlier challenge may also be possible.

IPR is meant to deliver speedier decisions than : challenges under the Hatch-Waxman Act, previously the only way to strip branded drugs of their legal protection. Although state universities have successfully invoked sovereign status, the Allergan-Mohawk deal is different, according to Zachary

"In the case of the universities, the patents originated with the university and were subsequently licensed to third parties," Silbersher says. "Rather, Allergan effectively rented the tribe's sovereign immunity, and it did so at the eleventh hour-after the IPR had already been pending for more than a year and was close to completion."

Allergan's Saunders in a Wall Street Journal editorial, had argued that the agreement with the tribe would help it preserve revenue to continue to develop its pipeline. Now, the strategy certainly won't pay off financially, and Allergan finds itself in the crosshairs of public outrage, much as Canonsbury, Pennsylvania-based Mylan did after its EpiPen pricing debacle (Nat. Biotechnol. 34, 1231-1241, 2016).

US Senator Claire McCaskill in a letter to PhRMA, a pharmaceutical trade group, warned that a widespread use of sovereignty could have a "devastating effect on consumers." In a follow-up McCaskill said she drafted a bill stating that tribal sovereign immunity cannot be used to block the review of a patent. In addition, four representatives from the House Oversight Committee launched a probe into the deal, stating "the exchange may impair competition across the pharmaceutical industry and ultimately dissuade companies from pursuing less-costly generic alternatives to brand drugs." And David Mitchell of the advocacy group Patients for Affordable Drugs called on PhRMA to "disavow" and "oppose" the drug maker's "legal dodge."

In turn, Saunders himself is asking for a review of the IPR process. Of course, this is the same route Allergan used earlier this year to invalidate a number of patents on a rival pain therapy that could have challenged its Botox treatment.

Eva von Schaper Munich
"[Gottlieb] has the potential to help people appreciate the FDA. It's happening at the irony, of course - at a time when people are questioning why we have regulatory agencies at all," said Joshua Sharfstein, former FDA official in the Obama administration. Gottlieb is considered a front runner to replace [disgraced] former secretary of health and human services Thomas Price. (STAT News, 4 October 2017)
"Cigarettes have a huge [label], but GMO is not cigarettes; it's not poison. There is nothing wrong with this from any perspective. Let's see what happens." UC Berkeley's David Zilberman was referring to the fact that genetically modified apples (Artic Apple) will not be labeled GMO. The antibrowning apples will have a $\mathrm{QR}$ code that links to a website with detailed information. (MIT Technology Review, 7 October 2017)
"The idea that we could choose not to do this, I think, is impossible. If we were to decide not to pursue human genome editing in the United States, it would still take place everywhere else in the world." Robert Truog, director of Harvard Medical School's Center for Bioethics, weighs in on the news that US scientists used CRISPR-Cas9 to edit out a disease-causing gene in embryos. (Harvard Gazette, 8 August 2017) 